\title{
Felipe IV: de la política a la literatura
}

\author{
Francisco Javier Díez de Revenga \\ Universidad de Murcia \\ revenga@um.es
}

Recepción: 21/07/2014, Aceptación: 03/09/2014, Publicación: 17/12/2014

\begin{abstract}
Resumen
La personalidad de Felipe IV ha trascendido la política para hallar eco en la literatura, la poesía, e incluso el teatro y la novela, con muy diferentes valoraciones. En este trabajo se analizan las numerosas fuentes literarias que glosan la figura del rey, desde sus contemporáneos hasta las representaciones más recientes, desde la narrativa hasta el cine.
\end{abstract}

Palabras clave

Felipe IV; política; literatura; mito; siglo XVII

\begin{abstract}
Philip IV: from Politics to Literature

The figure of Philip IV has extended from politics to literature, poetry, and even the theatre and the novel, with very different assessments. This paper analyses a large number of literary sources that comment on the figure of the king, ranging from his contemporaries to the most recent depictions, from narrative to film.
\end{abstract}

\section{Keywords}

Felipe IV; politics; literature; myth; xvII century 
La figura de Felipe IV es un reflejo claro, en su consideración histórica y más aún en la literaria y la poética, de las complejas relaciones existentes entre literatura y política. Y, de hecho, podemos convenir, al iniciar esta aproximación, que la personalidad de Felipe IV ha trascendido a la literatura, a la poesía, e incluso al teatro y a la novela, con muy diferentes valoraciones. Desde el opúsculo que el preceptista barroco José Pellicer de Tovar reunió en 1631, titulado Anfiteatro de Felipe el Grande, en el que los más granados ingenios del barroco español exaltaron la figura el monarca convirtiéndola en un mito viviente, hasta la novela de finales del siglo xx, de Gonzalo Torrente Ballester, Crónica del rey pasmado (1989), Felipe IV ha pasado a la historia literaria como un referente controvertido y enfocado de muy diversas perspectivas. La película de Imanol Uribe $E l$ rey pasmado (1991) superó con creces las ocurrencias de Torrente Ballester y mejoró el modelo narrativo en una prodigiosa cinta, que recupera un concepto del monarca acorde con la consideración que muchos intelectuales han venido a convenir sobre su personalidad.

Un trabajo excepcional, «Felipe IV y sus mujeres» de José Alcalá-Zamora Queipo de Llano, en el volumen que el mismo coordinó, Felipe IV. El hombre y el reinado, descubre la personalidad del monarca a la luz de sus aficiones y placeres: las mujeres, las fiestas, el teatro y los espectáculos. En los ambientes festivos y relajados era feliz y se sentía muy a gusto de acuerdo con lo que ya, hace muchos años, estableciera con precisión José Deleito Piñuela en su clásico El rey se divierte. Podríamos decir, si no incurriésemos en un juego de palabras, que Felipe IV sería la literatura mientras que el poderoso conde-duque de Olivares encarnaría la política. Y política y literatura serían la base de un reinado y el alimento de un monarca especialmente singulares. 


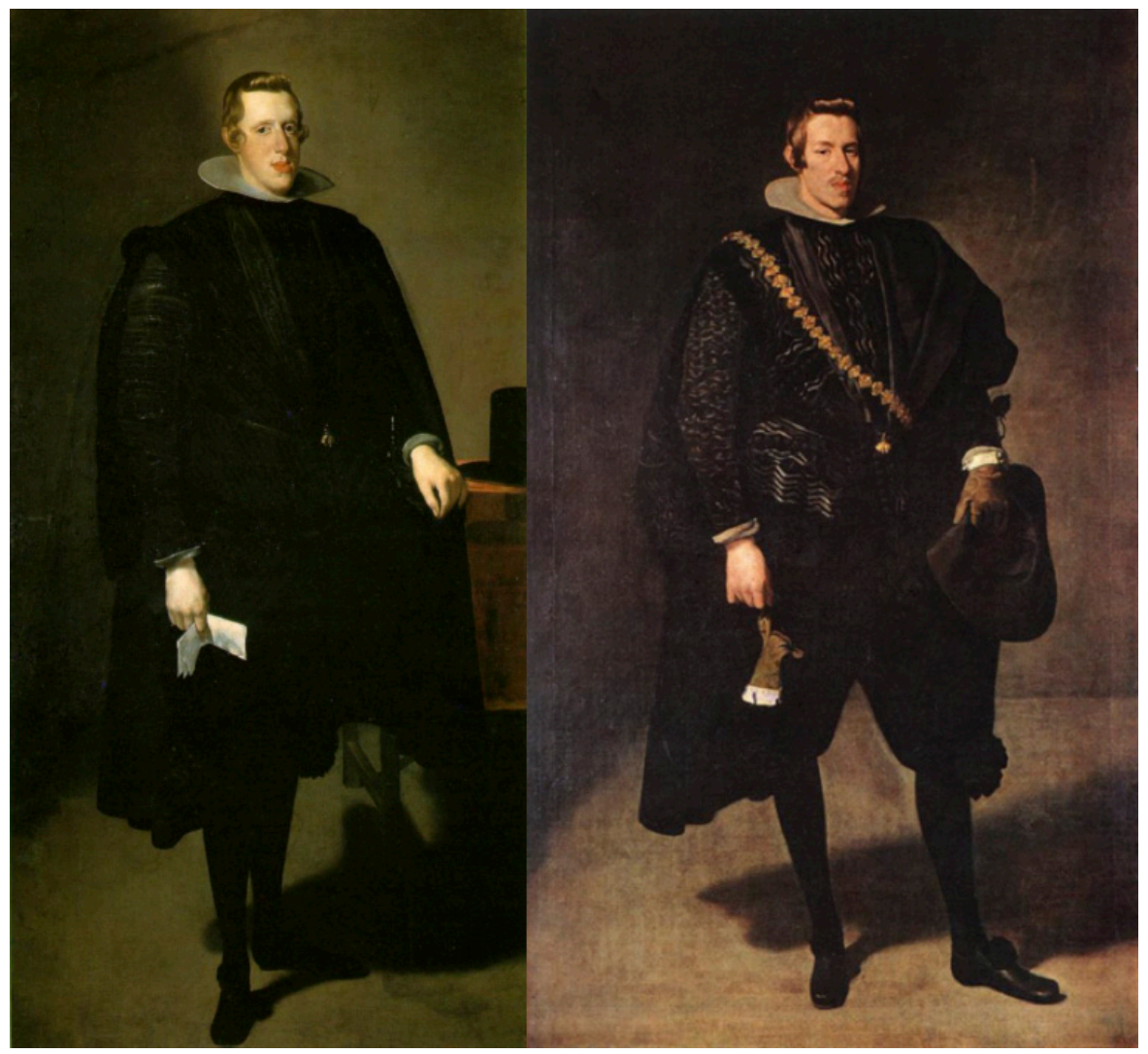

Diego Velázquez: «Felipe IV» (1624) Museo del Prado (izq.) y Diego Velázquez: «Retrato del Infante don Carlos» (1626) Museo del Prado (dcha.)

Algunos documentos sobre el controvertido monarca se han hecho particularmente célebres. Así el poema de Manuel Machado, publicado en la revista Electra el 23 de marzo de 1901, evocación de uno de los más conocidos retratos que realizara del monarca el gran pintor de su cámara Diego Velázquez que figuró en su libro Alma, de 1902, con el título de "Felipe IV» y con la dedicatoria al poeta y diplomático Antonio de Zayas, autor él mismo de otro poema inspirado en igual retrato velazqueño y con el mismo título, y que figuró en su libro Retratos antiguos, también de 1902.

El simbolismo, y sobre todo el parnasianismo de Manuel Machado nos legaron la figura de un rey, visto en el famoso retrato de 1624, abúlico y decadente, incapaz de tener en su mano el documento con el que le retrató el pintor, que Machado, en gesto genuinamente parnasiano, lo convirtió en el guante de ante que el hermano del rey, el infante don Carlos, ostenta en su propio retrato también de Velázquez (1626). Los tercetos encadenados sin cuarteto final (aunque 
lo parezca, no es un soneto, como he visto escrito en numerosas fuentes literarias merecedoras de total olvido), y el lenguaje arcaico y cortesano áureo crean un ambiente muy siglo diecisiete mientras que los símbolos empelados en el poema revelan decadencia, dejadez, hastío, cansancio, inacción, austeridad, aunque no ocultan, sin embargo, desmayada galanía:

Nadie más cortesano ni pulido que nuestro rey Felipe, que Dios guarde, siempre de negro hasta los pies vestido.

Es pálida su tez como la tarde, cansado el oro de su pelo undoso, y de sus ojos, el azul, cobarde.

Sobre su augusto pecho generoso, ni joyeles perturban ni cadenas el negro terciopelo silencioso.

Y, en vez de cetro real, sostiene apenas con desmayo galán un guante de ante la blanca mano de azuladas venas.

El dedicatario de este poema, Antonio de Zayas, duque de Amalfi, no se queda atrás en la interpretación simbolista y también parnasiana del personaje, a través del retrato de Velázquez. Ahora sí es un soneto el que recrea el mismo ambiente decadente, aunque inevitablemente advertimos en él un homenaje a su buen amigo Manuel Machado, que, como sabemos, le había dedicado su poema. Parnasiano al fin, Amalfi se detiene en el gusto por el placer y la sensualidad del monarca, algo que no había hecho su amigo:

Claros los ojos, pálida la frente,

el oro el cabello desteñido,

claro el rubio bigote retorcido,

grueso el labio, la barba prominente.

Correr Felipe por las venas siente

la noble sangre azul de su apellido,

de terciopelo negro revestido

y al cuello el timbre borgoñón pendiente.

Oculta el traje que severo luce

de amor y gloria el devorante fuego

que de sus noches el placer inquieta

Y a través de su risa se trasluce

que el rey sofoca y tapa el palaciego

sus ensueños de amante y de poeta. 
Y no podemos olvidar algunas obras de teatro como Cada cual con su razón (1839), de José Zorrilla, que recupera el Madrid de Felipe IV y las aventuras amorosas del monarca. En la obra de Zorrilla, el rey quiere abusar de Inés, la enamorada del noble don Pedro, del que se descubre que es hijo ilegítimo del soberano, y todo se arregla, no sin que la realeza quede bastante malparada en la obra. Otras obras de la escena romántica coincidieron con esta de Zorrilla en la presencia y actuación de Felipe IV como personaje dramático: Patricio de la Escosura, en La corte del Buen Retiro (1837), había recreado la vida cortesana con la aparición en escena de Velázquez, Góngora, Quevedo y Calderón de la Barca, además del rey, la reina y damas, caballeros, pajes y ujieres; y Antonio Gil de Zárate desarrolla las relaciones políticas del rey con el conde-duque en Un monarca y su privado (1840), también con la intervención, entre otros personajes, de Quevedo y Calderón, junto a criados, alguaciles, mozos y «varios poetas del tiempo de Felipe IV", tal como ha estudiado con todo detalle José Montero Reguera.

Hasta llegar a Las Meninas (1960) de Antonio Buero Vallejo, de cuyo estreno fue crítico teatral Gonzalo Torrente Ballester, quien veintinueve años antes de escribir su novela, destacaba el papel de Felipe IV en la obra: «Qué es esta "fantasía velazqueña" llamada "Las Meninas"? Yo la llamaría "hipótesis dramática", por cuanto nada de lo que en ella sucede ha sucedido verdaderamente, pero pudo suceder. Sabemos que Velázquez fue hombre combatido (¿cómo no si era un español de genio?), y que el rey Felipe IV le protegió y defendió. Buero Vallejo ha imaginado una trama en la que Velázquez aparece combatido y acusado, y en que el rey, quizá a pesar suyo, le defiende y protege. La trama tiene su origen en "La Venus del espejo", y de su solución depende que "Las Meninas" se pinten o no. Pero en esta trama, que pudo limitarse a mero episodio cortesano, Buero Vallejo ha implicado muchas cosas. Ante todo un "ambiente" espiritual y una "situación" histórica. La indudable lentitud de la primera parte obedece a que, sin ser expositiva, necesita de un gran espejo teatral para informarnos dónde estamos y de cómo son aquellas gentes y de cómo viven. Pintura nada halagüeña, pues se trata del período de mayor decadencia moral de Espańa, este tristísimo siglo en que el Destino, con su habitual sentido del humor, quiso que coexistieran los más grandes imbéciles y los mayores malvados con esa docena de genios del arte y de la poesía que constituyen, hoy por hoy, nuestro tesoro más seguro.»

En su edición de Las Meninas de Buero Vallejo, Virtudes Serrano señala la fortuna que Felipe IV y su época han tenido, a partir del estreno bueriano, en el teatro actual: El caballero de las espuelas de oro (1964) de Alejandro Casona, La Saturna (1973), Las alumbradas de la Encarnación (1979), La Monja Alférez (1986) y El libro de Salomón (1994) de Domingo Miras, La sombra del poder (1989) de Eduardo Galán y Javier Garcimartín, La amiga del Rey (1996) de Eduardo Galán, Por quién moría don Juan (1993) de Luis Federico Viudes, La puta enamorada (1999) de Chema Cardeña y Los espejos de Velázquez (1999) de Antonio Álamo.

La novela decimonónica también dejó algún que otro testimonio interesante sobre Felipe IV y su tiempo, como ocurre en El peluquero del rey (memorias 
del tiempo de Felipe IV) de Ramón Ortega y Frías (1860), extenso relato de 985 páginas editado por entregas, típico producto de la novela histórica de este escritor granadino caracterizado por la exuberancia episódica y los contenidos anecdóticos; hasta llegar a la novela actual, en la que ya hemos destacado la presencia de Gonzalo Torrente Ballester con la Crónica del rey pasmado, que alcanzó singular popularidad gracias a la versión cinematográfica de Imanol Uribe. Aunque el más constante y expresivo narrador contemporáneo, en relación con la época de Felipe IV, es, sin parangón alguno, Arturo Pérez-Reverte y su serie del capitán Alatriste. Diego Alatriste nace en el reinado de Felipe II, madura en el de Felipe III pero se desarrolla a comienzos del reinado de Felipe IV, de quien escribe Pérez-Reverte: «Tu rey es tu rey. Felipe IV es el monarca que el Destino nos dio, y no otro. Lo que encarnaba era lo único que tenemos los hombres de esta casta y de este siglo. Nadie nos ha permitido escoger. Era mucha España la que, para nuestra desgracia, fue a caer sobre sus hombros. Y él nunca fue hombre para semejante peso».

José Jaime García Bernal, en su trabajo «De "Felipe el Grande" al "Rey Pacífico". Discursos festivos y funerales durante el reinado de Felipe IV", estudia la evolución de la imagen del rey Felipe IV a partir de los discursos funerales y festivos que jalonan su largo reinado. Destaca el autor el gran potencial interpretativo de un género que estuvo en continua transformación y mantuvo un permanente diálogo con la historia, la leyenda y la mitología. Después de sentar los antecedentes retóricos del género epidíctico, distingue García Bernal dos etapas: la primera acuña la imagen heroica de «Felipe el Grande» y su espacio retórico propio: el teatro agonal del príncipe; la segunda describe la deriva del concepto de grandeza por las hazañas, hacia el de excelencia en la virtud y fidelidad a la religión que desemboca, al final del reinado, en la imagen del «Rey Pacífico».

En la literatura, lo mismo que en la representación plástica, la política del conde-duque procuró la exaltación del monarca por todos los medios. Jorge Gómez Gómez, en su trabajo "La autoridad de Felipe IV a través del arte», destaca cómo el arte se utiliza en forma de propaganda a través de las representaciones escultóricas y pictóricas de la figura del rey y de toda la familia real, para manifestar la majestad real y la grandeza del personaje.

En definitiva que Felipe IV, denominado «el Grande», es el más ostentoso mito viviente de la España del Siglo de Oro, o por lo menos de la dilatada época que le cupo vivir de ese siglo: vivió sesenta años, entre el 8 de abril de 1605 y el 17 de septiembre de 1665, y reinó durante 44 años, 5 meses y 16 días, en el reinado más largo de un monarca español, comenzado el 31 de marzo de 1621. Su figura fue hábilmente ensalzada a través de panfletos, relatos, exaltaciones en verso y relaciones en prosa, que circulaban por las imprentas de la época, y que hoy podemos leer en impresos cuya rareza no puede sorprendernos, aunque sí, en todos los caso, su extraordinario contenido. Es en las relaciones de estas fiestas donde encontramos, en ocasiones, manifiestos de este sentido de exaltación monárquica. Maravall señaló, hace muchos años, que «para la monarquía, tal 
vez lo más importante era escudarse frente a las discusiones y hostilidades de dentro, que tantos críticos excitaban, contra los cuales se servía aquella de recursos de procurarse la adhesión ciega, aturdida, irresponsables, de las masas. Uno de los mejores medios era mantenerla en fiestas».

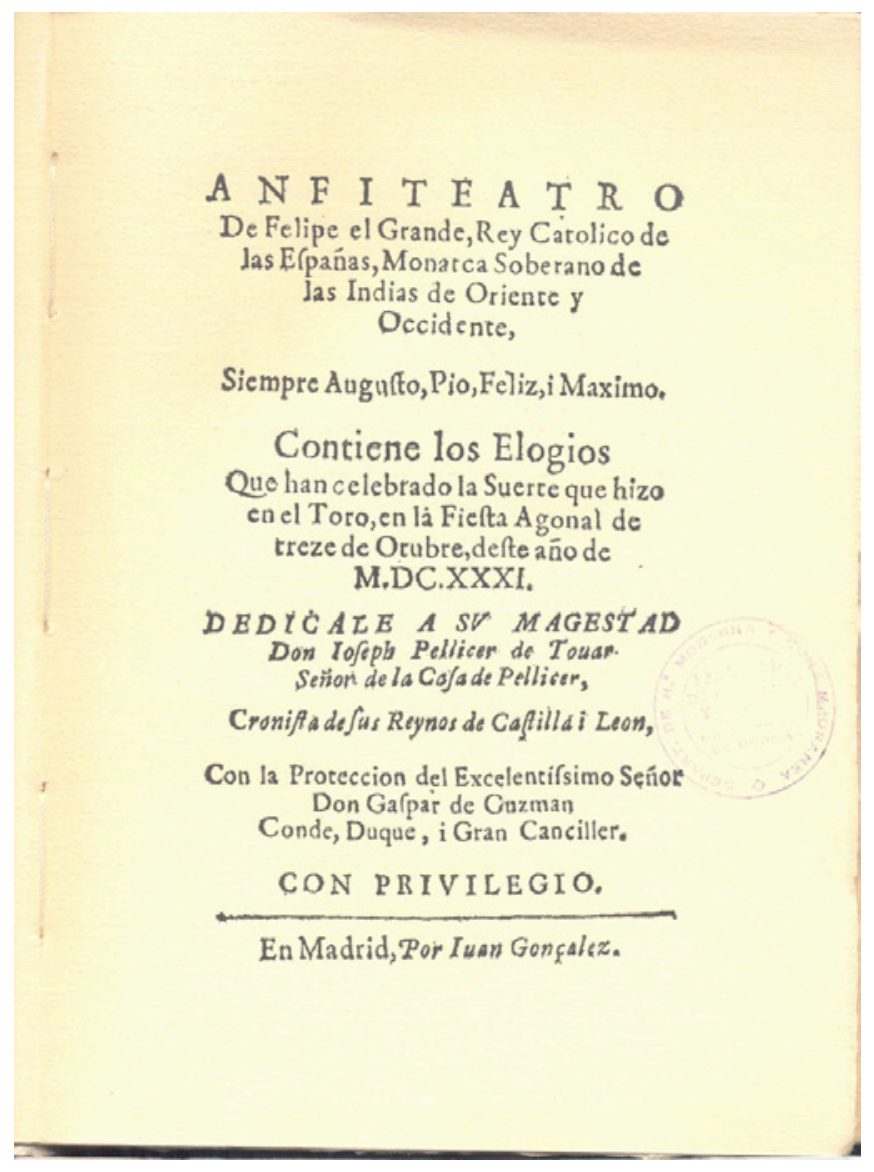

Anfiteatro de Felipe el Grande (Madrid, 1631)

Adhesión, admiración, mitificación, teatro, ostentación, teatralidad, pueden conjuntarse en una fiesta barroca, como aquella que, como aquella que se celebró en Madrid, en 1631, con gran ostentación para festejar un acontecimiento. Se llevó al extremo más asombroso, quizá más teatral, la artificiosidad barroca, y se montó una fiesta «a la romana», es decir, improvisando un anfiteatro que había de acoger el enfrentamiento entre un buen número de animales, escogidos entre distintas especies. Se conoce esta fiesta como el Anfiteatro de Felipe el Grande, y sabemos de ella por un curioso impreso titulado del mismo modo, Anfiteatro de 
Felipe el Grande, que, a su valor como informador de un aspecto interesante de la cultura barroca, une el de ser una extrańa joya bibliográfica ya que, como en su título se indica, «contiene los elogios que ha celebrado la suerte que hizo en el toro, en la fiesta agonal de trece de octubre de este año de MDCXXXI».

Y la hazaña no fue otra que, en el trascurso de una fiesta semipagana, preparada por el conde-duque de Olivares, el rey, desde el balcón de una panadería de la plaza del Parque (ya que la Plaza Mayor estaba en obras), donde se celebraba, dio muerte, disparándole un arcabuz, al bravísimo toro que había vencido sobre los demás animales.

El día 13 de octubre de 1631 Don Diego Saavedra Fajardo, diplomático destinado en Roma, de 47 años, se encontraba en Madrid en una misión secreta. A ello se refirió Quintín Aldea, cuando señalaba que «vino a España en misión secreta enviado por el conde de Monterrey, embajador espańol en Roma [...] El objeto de su misión fue, al parecer, el de formar parte de la famosa Junta que se constituyó en Madrid el 31-III-1631 [...] En la primera sesión, celebrada el 7-IX-1631, leyó don Diego un memorial, compuesto por él con la colaboración de Juan López Carcastillo, en donde se relataban todos los excesos jurisdiccionales de la Curia Romana y de la Nunciatura de Madrid». Sabemos que la tal Junta trabajó hasta septiembre de 1632, aunque Don Diego marcharía a un nuevo destino en Roma en abril de ese año. Poco más de un año, pues, le permiten vivir en la corte de Madrid y conocer las celebraciones y las fiestas que se organizan en la España de Felipe IV. Su condición de alto funcionario le permitía estar presente, con los poderosos, en las grandes ocasiones, y, de paso, medrar, ante ellos, un nuevo destino en su ya brillante carrera.

Estas son las circunstancias vitales del último poema que, por ahora, conocemos de Don Diego. Los editores de sus poesías, especialmente el conde de Roche y José Pío Tejera, y luego, con mayor difusión, Ángel González Palencia, dan buena cuenta de la presencia, entre las poesías de Saavedra, de su única obra poética de madurez, ya que las demás recogidas corresponden a 1612-1614, cuando nuestro escritor, con sus veintiocho años, se daba a conocer entre los políticos de su tiempo participando en las justas poéticas convocadas con motivo de la muerte de Margarita de Austria. Nos estamos refiriendo, claro está, a las poesías de circunstancias, porque posterior, posiblemente, es el soneto «Ludibria mortis», que, con tanta brillantez, cierra las Empresas políticas (1640).

Los lectores de las escasas poesías de Saavedra conocen las dos décimas, que fueron integradas por José Pellicer de Tovar en el Anfiteatro de Felipe el Grande:

Hoy luce constelación aquel bizarro animal que en el arena agonal triunfó de tigre y león. $\mathrm{Y}$ aunque sus hazañas son quien le coronan valiente, nunca su cerviz luciente 
estación fuera del sol,

si el Júpiter español

no fulminara su frente.

Transformación engañosa

contra el virginal decoro

trasladar pudo otro toro

a la zona luminosa.

Traslación fue no gloriosa

a una deidad tan severa:

más digno Júpiter fuera

quien, no con tan vil ensayo,

sino al imperio de un rayo,

nuevo signo da a la esfera.

El poema se recoge por primera vez en el libro antes citado, una de esas joyas bibliográficas inencontrables que, por suerte, llegó a pertenecer a Antonio Pérez Gómez en los años setenta, lo que permitió su reimpresión y que hoy podamos disponer de todo el conjunto de poesías que, con el mismo motivo, escribieron buen número de los ingenios españoles que vivían en Madrid aquel 1631. Pérez Gómez refiere, poco antes de su muerte (moriría al comenzar 1976), que fue su última adquisición el librito en cuestión, del que en España no había apenas ejemplares. Solo había sido editado previamente por el marqués de Jerez de los Caballeros en otra inencontrable edición de cien ejemplares, impresa en Sevilla, E. Rasco, en 1890. Jamás se ha vuelto a editar, a pesar de su indudable interés bibliográfico, poético, histórico, político y aun mítico. El mismo Pérez Gómez hace el recuento de los poemas que el libro incluye: 86 sonetos, 10 espinelas, 3 romances, una silva y unas estancias.

Es interesante recordar lo que escriben, en 1884, el conde de Roche y Pío Tejera, al incluir el poema ya dentro de una colección de obras del diplomático murciano, y cómo relatan que conocieron el poema por referencias, y gracias a la colaboración de algún otro bibliófilo amigo que les pudo comunicar, como ellos anotan tan puntualmente, al tiempo que citan a los traductores españoles de la Literatura de Ticknor, que "hay en él poesías de ochenta y seis ingenio de lo más florido y aventajado que a la sazón había en la corte». En una nota a pie de página, nuestros bibliófilos y eruditos dan cuenta, siempre citando a su ilustre comunicador, de todos los detalles en torno a la fiesta, aunque muy resumidamente. En cuanto al poema, lo transcriben modernizando su ortografía y deslizando una falta de concordancia en el verso sexto (corona por coronan) que pasa, junto a la nueva versión, a la edición de González Palencia. Como Roche y Tejera lo publicaban en 1884 no nos puede extrańar que juzgasen el poema con severidad, advirtiendo su excesivo culteranismo, pero perdonándolo o mirándolo con buenos ojos, porque su autor era quien era: "Que no es composición de mérito alguno, sino, antes al contrario, inficcionada por completo del virus del culteranismo, lo sabemos; pero no son mucho mejores las otras al mismo asunto 
dedicadas, y las vemos, sin embargo, figurar en varias colecciones famosas, siquiera no sea más que como ejemplo del gusto de la época».

La dureza del juicio sobre el poema, propio de la erudición de esa hora de España, no resta mérito alguno a la labor del conde de Roche y de Pío Tejera. Por cierto que también merece la pena conocer la figura del aristócrata murciano, al que dediqué recientemente un perfil biográfico sobre su vida y su obra asombrosas. Leer hoy el Anfiteatro de Felipe el Grande, gracias a la prudencia del buen Antonio Pérez Gómez, también estudiado por mí en diferentes oportunidades, que culminan en otro reciente perfil biográfico, es una de los más fértiles experiencias que se pueden tener con intención de disfrutar de un espectáculo muy del diecisiete y de la locura colectiva que se propagaba entonces a la hora de ensalzar al mito viviente más grande de una época llena de mitos: Felipe el Grande, nada menos que Felipe IV de España, «Júpiter» para nuestro Saavedra Fajardo, como para casi todos los demás ingenios de la corte.

En este ambiente, hay que contextualizar los términos del poema de Saavedra Fajardo, adecuadísimo a las circunstancias y al libro en que se incluye. No cabe duda de que se hace un flaco servicio a Saavedra si el poema se publica de la manera que se ha venido haciendo con la sola mención titular de "Al toro que mató Felipe IV", como ha figurado en las dos ediciones que conocemos. Es, en este caso, la circunstancia la que importa. Y en esta circunstancia están, entre otros, poemas de ingenios preclaros, cuya perfección no podemos negar, por la riqueza de una imaginación brillante y grandiosa que exalta, como Saavedra, la virtud real y la fiereza del bruto. Así Lope de Vega:

Desprecia invicto, y formidable espanta, selvas de fieras, animoso toro, encrespa la cerviz al cerco de oro, y con el bruto imperio se levanta.

Cuando el planeta, cuya sacra planta besas dos mundos, con marcial decoro tan breve rayo disparó sonoro, que ardiendo el toro al tiro se adelanta.

¡O fiera victoriosa! preferida al oso, al tigre y al león, tan fuerte, que de sola deidad fueras vencida.

Dichosa y desdichada fue tu suerte, pues como no te dio razón la vida, no sabes lo que debes a tu muerte.

No hay duda de que Lope parafrasea en su soneto las propias palabras de Pellicer de Tovar, haciendo referencia a la grandeza de la muerte del toro, ser sin razón, por haber perecido a manos de Felipe IV (sola deidad le llama Frey Lope). No se queda corto Quevedo, a la hora de acarrear mitología apropiada: 
En dar al robador de Europa muerte, de quien eres señor, monarca ibero, al ladrón te mostraste justiciero $y$ al traidor a su rey castigo fuerte.

Sepa aquel animal que tuvo suerte de ser disfraz a Júpiter severo, que es el León de España el verdadero, pues de África el cobarde se lo advierte.

No castigó tu diestra la victoria, ni dio satisfación al vencimiento: diste al uno consuelo, al otro gloria.

Escribirá con luz el firmamento duplicada seńal, para memoria, en los dos de tu acierto y su escarmiento.

Reitera imágenes y referencias míticas otro soneto del mismo Quevedo, que también será autor de uno de los romances incluidos en el volumen por Pellicer de Tovar:

En el bruto, que fue bajel viviente donde Jove embarcó su monarquía, y la esfera del fuego donde ardía cuando su rayo navegó tridente,

yace vivo el león que, humildemente, coronó por vivir su cobardía, y vive muerta fénix valentía, que de glorioso fuego nace ardiente.

Cada grano de pólvora le aumenta de primer magnitud estrella pura, pues la primera magnitud le alienta.

Entrará con respeto en su figura el sol, y los caballos que violenta, con temor de la sien áspera y dura.

No es tan malo como decían hace más de un siglo Roche y Tejera el poema de Saavedra Fajardo. Ni desde luego ininteligibles sus imágenes y referencias mitológicas. Antes bien revelan un claro ingenio y una buena imaginación para ligar el animal y su verdugo con la tradición mitológica más clásica y más de moda. La denominación de Júpiter para Felipe IV se justifica por el contexto pagano-romano de la fiesta y del anfiteatro, y además se contamina con la figura del toro, el «mentido robador de Europa» que llamara Góngora y que Quevedo 
recuerda en uno de sus sonetos. El toro-Júpiter no puede morir sino a manos del Júpiter (omnipotente dios) Felipe IV.

La idea de que la muerte a manos del monarca engrandece al pobre animal se repite con insistencia desde el prólogo de Pellicer y pasa desde luego a muchos de los poemas, entre ellos al de Saavedra Fajardo. No cabe duda que también está presente la relación toro-constelación tauro-transformación o metamorfosis de Júpiter en toro, que Góngora había encerrado en aquellos versos iniciales de la Soledades, para significar el mes de abril: «Era del año la estación florida / en que el mentido robador de Europa», y que posiblemente fueron los que influyeron a la hora de tachar Roche y Tejera la poesía de Saavedra como «inficcionada por completo del virus del culteranismo». Júpiter fue inmortalizado en la constelación de Tauro por una baja acción (raptar la virginidad de Europa) impropia de una divinidad tan seria (severa). Con la suerte que tuvo el toro en Madrid al caer a manos de Felipe IV, se hubiera dignificado la constelación, ya que tal hecho si es una hazaña capaz de dar "nuevo signo [...] a la esfera». Estas cosas imaginaba don Diego Saavedra mientras cumplía labores diplomáticas secretas en Madrid y elevaba vitales informes para la seguridad del Estado. Iba al «anfiteatro", veía a las fieras matándose, y cuando don Felipe dispara sobre el animal triunfante, para triunfar sobre el triunfador, Saavedra, que es funcionario del estado y, como Lope, como Quevedo, como tantos otros, tiene que sobrevivir, canta con todos ellos la hazaña del mayor mito de la época, la católica majestad de don Felipe «el Grande».

He aquí, otros textos en los que la exaltación política supera a la propia poesía y a la literatura. Así, el Príncipe de Esquilache:

$\mathrm{Al}$ golpe invicto de tu brazo fuerte, emulación del rayo de la esfera, rindió su aliento la intratable fiera, perdió la vida, ennobleció la muerte.

No estrecha tanto el límite la suerte; pues lo que honor en un contrario fuera, es dicha en quien ingrata no venera aquel favor, que entre la sangre vierte.

O fue temor, o natural respeto, sujetarle primero, que atrevida, la bárbara fiereza se lo estorbe.

Amor te dio el aplauso del efeto, que no es admiración rendir la vida, a quien sujeta la cerviz al orbe.

Antonio Hurtado de Mendoza glosa las prerrogativas imperiales, que dominan todo el orbe y que ostenta el glorioso Felipe: 
En denuedo alevoso, en campo abierto cedió sólo a tu imperio soberano el bruto, que a su rey osó tirano quitar la monarquía del desierto.

Más al aplauso que al destrozo muerto, la misma brevedad le halló temprano; que en las glorias, Felipe, de tu mano nada menos que admira que el acierto.

La fiera, al real estrago agradecida, lisonja hizo al morir, y no violencia, que antes llegó la muerte que la herida.

$\mathrm{Y}$ al brazo que ni al orbe es resistencia, feroz rindiendo la rebelde vida, muerte no pareció, sino obediencia.

El soneto de Gabriel Bocángel contiene numerosas variantes respecto al recogido en sus obras completas, e insiste en la figura de Júpiter para mitificar al monarca, evocado en su nombre en griego:

Júpiter ya venciste; ya se inclina todo animal a ser tu viva historia. No te cupo en la vida la victoria, la victoria escondiste en la ruina.

Muerte que ha menester fuerza divina hizo al teatro tu deidad notoria. no fulminó Filipo: con más gloria, quien a esperarle se atrevió, fulmina.

Hizo el deseo el tiro; obró la mano el golpe, cuando el bruto a doble herida su vida vio mortal, viva su suerte.

¡Oh gran golpe de dueño soberano!, que por el brazo le quitó la vida, y por el dueño le quitó la muerte.

Mientras que Juan Ruiz de Alarcón, tras insistir en el mito de Júpiter, el disparo del arcabuz le sugiere otro mito, Vulcano, por demás fogoso y explosivo:

El irlandés lebrel, al tigre hircano vence aplaudida la bicorne fiera; delinque aleve, cuando no venera al monarca de brutos africano.

Al escarmiento el Jove castellano 
(porque ofendido en él se considera) empuña y vibra desde la alta esfera la fábrica tonante de vulcano.

¡Oh real privilegio! ¡oh ley sagrada que aun es también de irracional viviente con natural instinto obedecida!

La fiera expone a su intención la frente, y la mano respeta arrodillada, cuando postrada al rayo da la vida.

Luis Vélez de Guevara insiste en el poder universal del monarca revelado en las imágenes y en los topónimos:

Cuarto planeta, cuya luz aclama tanto horizonte, que tu nombre adora, dos veces del ocaso, y de la aurora en repetido mundo ardiente llama:

ese lunado bruto, que de fama hidrópico, tus rayos enamora, campańas pazca de zafir agora, pues tan alta ambición bebió a Jarama.

Mas fiera ya, que intrépida y valiente mereció la atención de luz tan grave, no se estreche a ser astro solamente;

pase a deidad, que en menos ser no cabe quién de su muerte vive inmortalmente, quién lograr de tu mano esferas sabe.

Nuevamente el mito de Júpiter, cuarto planeta y mentido robador de Europa, inspira al gran don Pedro Calderón de la Barca para su evocación del anfiteatro español convirtiendo el arcabuzazo en uno de esos rayos suyos, de Júpiter-Felipe, que no cesan de asombrar:

Si viste ¡oh Licio! a material esfera la fábrica celeste reducida, y en diversas especies dividida la cinta en quien el sol más reverbera;

tal el anfiteatro español era, zodiaco de imágenes con vida, cuando el cuarto planeta vio encendida la piel manchada de una y otra fiera. 
al desplegar su luz, la veloz tropa se ahuyentó, y el toro en la campańa amenazaba a Europa otro desmayo:

Pero ¿̇ué importa que el ladrón de Europa mentido triunfe, como el sol de España contra su frente esgrima el primer rayo?

Y, por último, Francisco de Rojas Zorrilla, muestra una vez más el imperio universal del mítico Filipo, nuestro rey Felipe IV.

Recele de Filipo el otomano

menos ya las vitorias que su intento, que es en Filipo acierto el pensamiento, $\mathrm{y}$ aun piensa menos que acertó su mano.

Con el venablo, si fatiga el llano, ofrece en el amago el escarmiento: lo visible es en él poco elemento; despojo es suyo lo que aun no es humano.

Diga, pues, si a su brazo prodigioso ni el plomo engańa, ni el objeto miente, el mundo ser efecto milagroso;

Si errara la diadema del Oriente: que acertar en Felipe es lo forzoso, y ni aun errar en él es contingente.

Casi todos los poetas, y solo hemos recogido los sonetos de los más conocidos y célebres, en el conjunto poético más recargado acaso de toda esta época, comparan al monarca con Júpiter con lo que provocan un contagio mental entre el contexto evocado (una fiesta romana y pagana), la hazańa del rey (matar a un toro, símbolo de Júpiter, «mentido robador de Europa») y la grandeza del hecho (propia del Júpiter español, Felipe el Grande). El arcabuzazo se convertirá en uno de sus míticos rayos. La mitificación está clara y la intención y el espíritu del impreso no son otras que exaltar esa mitificación. Tras detectar en los poemas recogidos en el opúsculo sus símbolos e imágenes míticas, es indispensable hacer alguna referencia a la relación mito-fiesta, encarnados estos conceptos (mito y fiesta) en la figura de Felipe IV y en el anfiteatro que montaron las gentes a su servicio para mitificar más su real persona. Política y literatura confluían una vez más.

Uno de los partícipes en este anfiteatro, Diego Saavedra Fajardo, en sus Empresas politicas, recomendaba al futuro rey que representase su papel de monarca con la dignidad propia de una real persona: «Baste en él —escribía Saavedrauna graciosa armonía natural en sus partes, que descubra un ánimo dispuesto y varonil, a quien el arte dé movimiento y brío, porque sin él las acciones del 
Príncipe serían torpes, y moverían al pueblo a risa y a desprecio». Y, más adelante, añade estas otras consideraciones: «lo precioso y brillante en el arreo de su persona causa admiración y respeto, porque el pueblo se deja llevar de lo exterior, no consultándose menos el corazón con los ojos que con el entendimiento».

Baquero Goyanes se refirió al carácter teatral, casi lección de escuela de arte dramático, de todas estas recomendaciones de Saavedra fajardo y señaló la relación teatro-política aludiendo al tema del gran teatro del mundo en las Empresa políticas. A Felipe IV, en su anfiteatro de Felipe el Grande, lo hallamos, gracias al poder transfigurador de las representaciones poéticas realizadas para la ocasión, desempeñando su papel — de rey y de mito - en ese gran teatro de la vida que a él le tocó protagonizar. Teatro, por lo demás, artificial y ostentoso, artificioso, en definitiva, que da muestras de una relación entre la política y la literatura absolutamente excepcional y singular.

Son muy interesantes a la hora de valorar esta relación política-literatura de la época aludir con detalle y detenerse, por último, en el montaje del anfiteatro y en la configuración del mito viviente, el rey Felipe IV.

No se puede poner en duda que el propio montaje está en relación directa con el carácter mítico que se quiere atribuir a la figura del rey. La información de que se dispone de aquel acontecimiento suministra datos que inducen al lector contemporáneo a convencerse que la fiesta, más que para regocijo popular, se hacía para exaltación y engrandecimiento de la monarquía católica del rey Felipe. Desde el motivo que la justificaba y producía, el cumpleaños del príncipe Baltasar Carlos, nacido el 17 de octubre de 1629, pone de relieve la relación fiesta-familia real. Pellicer, que no oculta, en efecto, en ningún momento su entusiasmo hacia la fiesta y exaltación del monarca, se refiere en la «noticia del espectáculo de las fieras», incluida en su volumen, a "aquella solemnidad raras veces celebrada en Castilla, y vista muchas veces en Roma en tiempo de sus césares», y recrea el ambiente romano-imperial adecuado que ha de caracterizar todo el montaje del espectáculo.

Sus referencias a Grecia y a los juegos olímpicos, pitios, nemeos e istmios en honor de Júpiter, Apolo, Achemoro y Neptuno, son muy significativos y pertinentes, ya que conducen a la conclusión del carácter mítico de las fiestas romanas, que ahora se imitan en Madrid. Y Roma es el modelo indiscutible: "comenzó a honrar sus ídolos y a solemnizar sus victorias en sus circos o anfiteatros con los juegos gladiatorios», y continuó con toda clase de fiestas: ferales, agonales... La relación con el montaje madrileño no se hace esperar en las palabras introductorias de Pellicer: «quiso el excelentísimo conde-duque renovar aquel ejercicio que tanto aplaudió el foro romano y festejar a las majestades católicas de Felipe el Grande y Doña Isabel de Borbón, reyes nuestros, con hacerle una fiesta al uso antiguo de Roma».

La grandeza de la fiesta se basa también en la presencia de los animales que «entraron en la arena a temerario duelo" y su relación, en la pluma de Pellicer está enriquecida debidamente por las alusiones míticas representada en cada 
uno de estos animales: «concurrieron el león, rey de las fieras, cuya obediencia ya tantas veces se ha visto jurada en Albania y África, cuantas Eliano y Solino encarecen. La tigre hircana, que en ferocidad y ligereza jamás cedió a ninguna en los montes», y así el oso, el toro, el caballo, el lebrel, y otros menores, en típico gesto trágico-cómico barroco, "que sirviesen a la risa y al entretenimiento». La concurrencia de personalidades fue, como era de esperar, al máximo nivel: reyes, príncipes, obispos, consejeros, embajadores, grandes de España, títulos y caballeros. Hasta tal punto que Pellicer no duda en exclamar: "Jamás vio Roma en sus escańos, ecuestres o plebeyos, mayor ni más lúcido concurso».

La fiesta discurrió de la siguiente forma: el toro se hace dueño del circo y, después de acobardar a sus enemigos, no es posible someterlo dada su extraordinaria fiereza, que impedía que nadie se aproximase a él. Solo «unos hombres, que cubiertos de una artificiosa tortuga de madera, que movían ciertas ruedas, iban dentro para instigar a los animales, con picarlos, a que lo embistiesen". Artificioso invento barroco que de nada valió. Solo la certeza y habilidad del rey pudo acabar, por medio del tan citado arcabuzazo, con la temida fiera.

La máxima mitificación de todo el acontecimiento corresponde a la figura del monarca, y las referencias que nos transmite Pellicer en sus palabras introductorias, responde a esta intención con toda claridad. Y no solo en aquellas alusiones contenidas en la «Noticia», que venimos citando, sino también en toda la serie de textos que abren el volumen, comenzando por la censura misma, realizada por Lope de Vega. En ella, el Fénix escribe, para ir entrando en ambiente, las siguientes palabras: «Esta acción de Su Majestad que trasladó su singular destreza del campo del anfiteatro, y del monte solo, al espectáculo universal sin que se debiese tan peregrino suceso a la Fortuna por accidente, sino a la ciencia por ejercicio, y a la gracia que el cielo para toda obra militar heroica, ha dotado su real naturaleza...».

Comparables estas líneas a las que el propio Pellicer dirige al rey en uno de los prólogos, en los que se insiste en la «acción heroica», en los «aciertos de V.M. así como son los mayores y más gloriosos que han acontecido» o en «la experiencia de su singular destreza, siendo aún más digna de ponderar la resolución de aventurarse la contingencia, que la certidumbre del acierto, después del riesgo».

Merece lectura detenida y comentario la dedicatoria del libro al conde-duque de Olivares, «atento a las glorias de Su Majestad, que Dios guarde», y «quien tanta parte tiene en todas", en la seguridad para Pellicer de que «ha de ser bien visto de V. E. todo aquello que resultare en grandeza suya (del rey)». Y continúa el colector: «y también creo que será lisonja para V. E. cualquiera demostración con que se festejaren sus reales aciertos». Le asegura que "celebran a su príncipe los mayores espíritus de nuestra nación» con «aplauso al acertado golpe, con que ilustró aquella fiesta», para lo cual pide la protección y el amparo del condeduque, como mecenas y protector, pues «empeñado su nombre de V. E. en ellos, es fuerza que tengan buena fortuna».

Pero la más informativa y expresiva de la exaltación política del monarca en un texto literario, se manifiesta en otro de los prólogos de Pellicer, el dirigido «a 
los curiosos», en el que lleva a cabo la definitiva mitificación, dado que el tipo de fiesta, con su carácter clásico-romano, es el que a las comparaciones y exaltaciones mitificadoras. Precisamente, la justificación de la publicación de los distintos poemas de los ingenios de la época se basa en lo siguiente: «supuesto que los espíritus más famosos del primer siglo y los más célebres poetas de la media edad, si se examinan con seso, se verá que no escribieron otra cosa que himnos y panegíricos a sus héroes y césares, desde Orfeo hasta Claudiano».

Como hay toro por medio, Pellicer compara a Felipe IV con Hércules, Jasón y Teseo, cuyas hazañas, recordadas con todo detalle, son superadas por el propio monarca. Incluso plantea Pellicer, en su condición de reputado preceptista, el problema de la verosimilitud para asegurar que ahí está la diferencia entre los héroes clásicos y el monarca. Mientras las enseñanzas de aquellos no eran sino fabulaciones, la del monarca es tan verdadera como real: «Por ellos verá el mundo que nuestro monarca, aun burlando, acierta, y confesará esta acción por verdadera la envidia misma, ventajosa a la de los tres que alcanzaron el título de semidioses por las suyas. ¿Con cuánta mejor causa pudiera Felipe conseguir aquellos renombres, si cuanto premio pudiera darle Fortuna, no lo hubiera, como merecido, heredado?».

Acaso con mayor relevancia donde se destaca de una forma más relevante la mitificación de Felipe IV es en la descripción de la escena, en el relato del momento en que el rey concede la mayor de las mercedes, la más excelsa de su gracias, permitirle morir a sus manos, «supuesto que entró en aquel anfiteatro a morir». Nos hallamos ante la imagen del monarca que propugnaba en sus Empresas politicas Saavedra Fajardo, aquel que cuidase los movimientos, el gesto, el ademán, la compostura en definitiva. Si lo hizo Felipe en aquella ocasión solemne no lo sabemos, pero lo cierto es que tal como trasmite los acontecimientos Pellicer de Tovar nos hallamos ante una figura barroca, parece que extraída de una comedia de la época: «Viendo pues nuestro césar imposible despejar el circo de aquel monstruo español, porque los que pudieran desjarretarle, le hallaban defendido en los demás animales que le huían, pidió el arcabuz enseñado en los bosques a semejantes empresas, y sin perder de la mesura real, ni alterar la majestad del semblante con ademanes, le tomó con gala y componiendo la capa con brío y requiriendo el sombrero con despejo, hizo la puntería con tanta destreza y el golpe con acierto tanto, que si la atención más viva estuviera acechando sus movimientos, no supera discernir el amago de la ejecución y de la ejecución el efecto. Pues encarar la frente el cañón, disparar la bala y morir el toro, habiendo menester forzosamente tres tiempos, dejó de sobra los dos gastando solo un instante en tan heroico golpe».

Señalaba Maravall, aludiendo a panfletos y opúsculos de este tipo que abundaron en la España de Felipe IV, que todo ello «respondía muy bien a la popularidad admirativa del Barroco». Desde luego, el interés que tiene ahora este interesante documento para entender una época y un tiempo reside en que, en realidad, no es sino un reflejo claro de la actitud de una determinada sociedad 
ante la monarquía. El gusto por la hipérbole, por lo artificioso y recargado de la cultura barroca, traspasaba la obra artística y se confundía con la existencia real. $Y$ en ese afán por exaltar la figura del monarca que propiciaba el omnipotente conde-duque de Olivares (la dedicatoria del libro a su persona así lo confirma), la literatura se ponía al servicio de la política, y los más afamados escritores se prestaban indefectiblemente a exaltar el objeto político que más le interesaba al gobernante, al conde-duque: la figura del rey, su majestad y su grandeza, garantía de la estabilidad del Estado y de la monarquía católica de Felipe el Grande. Política y literatura se confundía y de manera asombrosa en este caso. 


\section{Bibliografía}

Alcalá-Zamora Queipo de Llano, José, «Felipe IV y sus mujeres», Felipe IV. El hombre y el reinado, Madrid, Real Academia de la Historia, 2005.

Aldea Vaquero, Quintín (ed.) Diego Saavedra Fajardo, Empresas Políticas, Madrid, Editora Nacional, 1976.

Baquero Goyanes, Mariano, «El tema del gran teatro del mundo en las Empresas de Saavedra Fajardo", Monteagudo, 1, 1953.

Deleito Piñuela, José, El rey se divierte, Madrid, Espasa Calpe, 1935.

Díez de Revenga, Francisco Javier, «Enrique Fuster, conde de Roche: aristocracia y cultura", Tonos. Revista Electrónica de Estudios Filológicos, 23, 2012. <http:// www.um.es/tonosdigital/znum23/secciones/perfiles-2-perfil_reche.htm>

—, «Antonio Pérez Gómez, la ciencia del bibliófilo». Tonos. Revista Electrónica de Estudios Filológicos, 22, 2012. http://www.um.es/tonosdigital/ znum22secciones/perfiles-2-antonio_perez_gomez_perfil_td_ilustrado.htm

Escosura, Patricio de la, La corte del Buen Retiro, Madrid, Imprenta Hijos de Catalina Pińuela, 1837.

García Bernal, José Jaime, «De "Felipe el Grande” al "Rey Pacífico”. Discursos festivos y funerales durante el reinado de Felipe IV", Obradoiro de Historia Moderna, 20, 73-104, 2011.

Gil de Zárate, Antonio, Un monarca y su privado, Madrid, Imprenta de Yenes, 1841.

Gómez Gómez, Jorge, «La autoridad de Felipe IV a través del arte», en El universo simbólico del poder en el Siglo de Oro, ed. Álvaro Baraibar y Mariela Insúa, Nueva York/Pamplona, Instituto de Estudios Auriseculares (IDEA)/ Servicio de Publicaciones de la Universidad de Navarra, 2012.

González Palencia, Ángel (ed.), Saavedra Fajardo, Obras completas, Madrid, Aguilar, 1946.

Machado, Manuel, Poesías completas, edición de Antonio Fernández Ferrer, Sevilla, Renacimiento, 1993.

Maravall, José Antonio, La cultura del Barroco, Barcelona, Ariel, 1980.

Montero Reguera, José, "Calderón de la Barca sale a la escena romántica», Estudios de literatura española de los siglos XIX y XX. Homenaje a Juan María Diez Taboada, Madrid, CSIC, 1998, págs. 324-329.

Ortega y Frías, Ramón, El peluquero del rey (memorias del tiempo de Felipe IV) de (1860), Madrid, Manini Hermanos, 1860.

Pellicer de Tovar, José, Anfiteatro de Felipe el Grande, Madrid, 1631, edición facsimilar de Antonio Pérez Gómez, Cieza, Ediciones Conmemorativas «la fonte que mana y corre», 1974.

Pérez-Reverte, Arturo, El capitán Alatriste, 16a edición, Madrid, Alfaguara, 2005.

Roche, conde de y Tejera, José Pío, Saavedra Fajardo. Sus pensamientos, su poesías, sus opúsculos, Madrid, Fortanet, 1884. 
SaAvedra Fajardo, Diego, Empresas Políticas, edición de Francisco Javier Díez de Revenga, Barcelona, Planeta, 1988.

Serrano, Virtudes (ed.), Antonio Buero Vallejo, Las Meninas, Madrid, Espasa Calpe, 2013.

Torrente Ballester, Gonzalo, «Estreno de Las Meninas en el Español», Arriba, 10 de diciembre de 1960 .

-, Crónica del rey pasmado, prólogo de Santiago Castelo, Madrid, Espasa Calpe, 1994.

Zayas, Antonio de, Obra poética, edición de Amelina Correa, Sevilla, Fundación José Manuel Lara, 2005.

Zorrilla, José, Obras completas, ordenación, prólogo y notas de Narciso Alonso Cortés, Valladolid, Santarén, 1943. 
